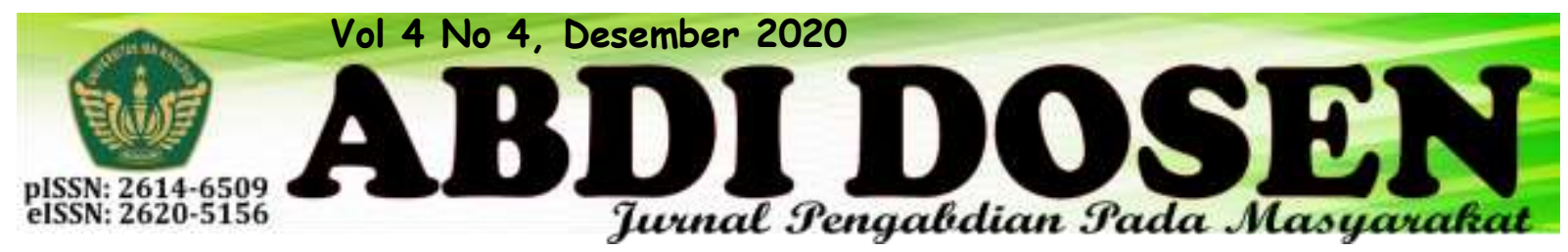

\title{
EDUKASI GIZI SEIMBANG SEBAGAI PERISAI PENULARAN COVID- 19 PADA KADER POSYANDU BINA SEJAHTERA DAN POSYANDU TULIP
}

\author{
Taufik Firdaus Alghifari Atmadja ${ }^{1}$, Dwi Sulistyaningsih ${ }^{2}$, dan Ifa Rifatul Mahmudah ${ }^{3}$ \\ taufiq.firdaus@unsil.ac.id 1 \\ dwi.sulistyaningsih@unsil.ac.id 2 \\ ifa.rifatul@unsil.ac.id 3 \\ Universitas Siliwangi, Tasikmalaya. 1,2,3
}

\begin{abstract}
The addition of positive confirmed cases of COVID-19 in Indonesia continues to occur. Ciamis Regency, which is geographically far from the center of the spread of COVID-19 in Indonesia, cannot be separated from the target of the spread. One of the efforts to prevent virus transmission is by increasing the immune system through balanced nutritional intake. Based on the results of the situation analysis in the Muktisari Village area, information was obtained that the community did not understand the relationship between balanced nutrition and the immune system. The habit of consuming foods with unbalanced nutrition, not paying attention to food safety in processing, and not implementing clean and healthy living habits are problems that must be resolved. Providing education to Posyandu cadres who act as mediators of health information services in the community is expected to be the first step in solving problems. Balanced nutrition education consists of material presentation using power point media and booklet media as well as cooking demonstrations. The positive response of participants to educational activities can be seen from the activeness of the participants, both during the discussion session and during the cooking demonstration. Based on the results of pre-test and post-test data processing, the n-gain value obtained is 0.2. This shows that there is an increase in the understanding of Posyandu cadres before and after the provision of balanced nutrition education
\end{abstract}

Keyword : balanced nutrition, COVID-19, posyandu cadres

\begin{abstract}
ABSTRAK
Penambahan kasus terkonfirmasi positif COVID-19 di Indonesia terus terjadi. Kabupaten Ciamis yang secara geografis jauh dari pusat penyebaran COVID-19 di Indonesia pun tidak lepas dari sasaran penyebaran. Upaya pencegahan transmisi virus salah satunya dengan meningkatkan sistem imun melalui asupan gizi seimbang. Berdasarkan hasil analisis situasi di wilayah Desa Muktisari, diperoleh informasi bahwa masyarakat belum memahami keterkaitan antara gizi seimbang dan sistem imum. Kebiasaan mengkonsumsi masakan dengan gizi yang tidak seimbang, tidak memperhatikan keamanan pangan dalam pengolahan, serta tidak menerapkan perilaku hidup bersih dan sehat menjadi masalah yang harus dituntaskan. Pemberian edukasi terhadap kader Posyandu yang berperan sebagai mediator pelayanan
\end{abstract}


informasi kesehatan di lingkungan masyarakat diharapkan dapat menjadi langkah awal penyelesaian masalah. Edukasi gizi seimbang terdiri dari pemaparan materi menggunakan media power point dan media booklet serta kegiatan demo masak. Respon positif peserta terhadap kegiatan edukasi terlihat dari keaktifan peserta, baik pada saat sesi diskusi maupun pada saat demo masak Dengan menggunakan instrumen pre-test dan post-test yang berjumlah 15 soal pilihan ganda, dampak dari kegiatan edukasi dapat terlihat. Berdasarkan hasil pengolahan data pre-test dan post-test, nilai n-gain yang diperoleh adalah sebesar 0,2. Hal menunjukkan bahwa terdapat peningkatan pemahaman kader Posyandu sebelum dan sesudah pemberian edukasi gizi seimbang.

\section{Kata Kunci: gizi seimbang, COVID-19, kader posyandu.}

\section{PENDAHULUAN}

Penyebaran COVID-19 telah terjadi hampir di seluruh daerah di Indonesia. Gugus Tugas Percepatan Penanganan COVID-19 dalam portal Satgas Penanganan COVID-19 mencatat penambahan kasus terkonfirmasi positif COVID-19 per tanggal 13 Juni 2020 totalnya menjadi 37.420 setelah ada penambahan sebanyak 1014 orang dari hari sebelumnya. SARS-CoV-2 yang menyebabkan adanya COVID-19 ini tergolong virus yang baru bagi sistem imun tubuh manusia sehingga tidak semua orang memiliki sistem imun alami yang dapat melawan virus tersebut. Hal inilah yang menjadi salah satu penyebab penyebaran COVID-19 terus meningkat sejak awal terdeteksi. Pencarian vaksin untuk membentuk sistem imun serta obat untuk mencegah SARSCoV-2 bereplikasi masih dilakukan.

Untuk saat ini, pendekatan yang digunakan untuk mencegah transmisi SARS-CoV-2 tersebut salah satunya dengan memastikan sistem imun tubuh dapat berfungsi dengan baik, sebagaimana anjuran yang sangat ditekankan oleh Kementerian Kesehatan Republik Indonesia. Seseorang yang memiliki respon imun yang tidak adekuat akan menyebabkan replikasi virus dan kerusakan jaringan (Susilo et al., 2020). Cara untuk menjaga sistem imun supaya dapat berfungsi dengan baik adalah dengan asupan gizi yang cukup (Calder, 2020; Ibrahim and El-Sayed, 2016). Asupan gizi yang seimbang terutama vitamin dan mineral tersebut sangat diperlukan dalam mempertahankan sistem imun yang optimal. Dalam Peraturan Menteri Kesehatan Republik Indoesia Nomor 41 tentang pedoman gizi seimbang, dikatakan bahwa gizi seimbang merupakan susunan pangan sehari-hari yang mengandung zat gizi dalam jenis dan jumlah yang sesuai dengan kebutuhan tubuh, dengan memperhatikan prinsip keanekaragaman pangan, aktivitas fisik, perilaku hidup bersih dan memantau berat badan secara teratur dalam rangka mempertahankan berat badan normal untuk mencegah masalah gizi. Gizi seimbang tidak hanya tentang bagaimana kita memperhatikan asupan pangan yang berasal kelompok pangan yang berbeda, tetapi juga disertai aktivitas fisik, dan Pola Hidup Bersih dan Sehat (PHBS). Asupan pangan yang sehat dikhawatirkan akan terkontaminasi zat asing apabila dalam pengolahannya tidak memperhatikan higienitas. Selain itu, asupan pangan yang masuk ke dalam tubuh pun harus 
memperhatikan seberapa banyak aktivitas yang dilakukan. Oleh karena itu, ketiga hal tersebut sama-sama penting untuk diterapkan terutama di masa pandemi ini.

Edukasi mengenai asupan gizi seimbang sebagai perisai COVID-19 penting untuk disampaikan kepada semua lapisan masyarakat. Penyampaian yang dilakukan tentu saja harus efektif, tepat sasaran dan tepat guna. Langkah penyampaian dapat diawali dari pihak yang berperan besar sebagai mediator pelayanan terkait gizi kepada masyarakat salah satunya adalah kader Posyandu. Menurut Tse et al., (2017), peran kader Posyandu secara langsung berhadapan dengan berbagai permasalahan masyarakat termasuk masalah kesehatan yang dihadapi oleh masyarakat. Oleh karena itu dengan memberikan edukasi pada kader Posyandu, diharapkan informasi akan tersebar merata kepada semua lapisan masyarakat.

Di Kabupaten Ciamis, kasus positif COVID-19 yang tercatat pada portal Pusat Informasi \& Koordinasi COVID-19 Provinsi Jawa Barat berjumlah 1 orang. Beberapa desa dapat dikatakan bebas dari COVID-19, salah satunya Desa Muktisari. Meskipun demikian, protokol kesehatan tetap harus diterapkan di lingkungan masyarakat. Berdasarkan hasil observasi, beberapa aktivitas masyarakat di Desa Muktisari berjalan seperti biasanya. Sebagian masyarakat terlihat masih sedikit abai dengan gizi seimbang, termasuk di dalamnya kebiasaan PHBS. Aktivitas masyarakat yang keluar masuk wilayah desa dan sebagian di antaranya merantau keluar kota seharusnya menjadi perhatian semua masyarakat untuk tetap waspada dan menerapkan gizi seimbang sebagai perisai COVID-19. Berdasarkan informasi tambahan melalui wawancara terhadap ibu-ibu kader Posyandu Desa Muktisari, diperoleh informasi bahwa sebagian masyarakat termasuk kader Posyandu belum mengetahui kaitan penting antara gizi seimbang dan pencegahan COVID-19, bahkan konsep gizi seimbang pun banyak yang masih belum memahaminya dengan benar. Pemahaman gizi seimbang yang belum dimiliki oleh masyarakat berdampak pada tidak teraturnya pola makan serta tidak rutinnya pembiasaan PHBS. Pola makan yang tidak memperhatikan kandungan gizi karena anggapan bahwa rasa kenyang sebagai indikator gizi cukup serta perilaku yang tidak memperhatikan kebersihan dan kesehatan, seperti ketidakdisiplinan pemakaian masker dan mencuci tangan inilah yang dikhawatirkan akan membuat sistem imun tubuh masyarakat rendah dan rentan terinfeksi virus di masa pandemi COVID19.

Tidak semua kader Posyandu aktif menggali sendiri informasi atau pengetahuan yang berkaitan dengan kaitan gizi seimbang dan pencegahan COVID-19. Padahal idealnya seorang kader Posyandu harus mampu menyediakan informasi mutakhir mengenai kesehatan, termasuk gizi seimbang yang perlu diperhatikan pada masa pandemi COVID-19. Minimmnya penyuluhan juga menjadi salah satu penyebab kurangnya pemahaman tersebut. Berdasarkan kondisi peningkatan jumlah positif COVID-19 yang signifikan, urgensi keterkaitan asupan gizi seimbang dalam meningkatkan imun, dan COVID-19 serta keadaan di masyarakat, khususnya kader Posyandu yang belum memahami peran gizi seimbang sebagai perisai COVID-19, 
maka perlu diadakan pengabdian kepada masyarakat yang dapat memberikan edukasi mengenai gizi seimbang sebagai perisai COVID-19.

\section{METODE PELAKSANAAN}

Pengabdian pada masyarakat yang telah dilakukan bertujuan untuk memberikan edukasi mengenai gizi seimbang meliputi asupan pangan seimbang dan PHBS sebagai upaya pencegahan diri dari COVID-19. Adapun metode pelaksanaan pengabdian terdiri dari lima tahap seperti yang dapat dilihat pada Gambar 1 .

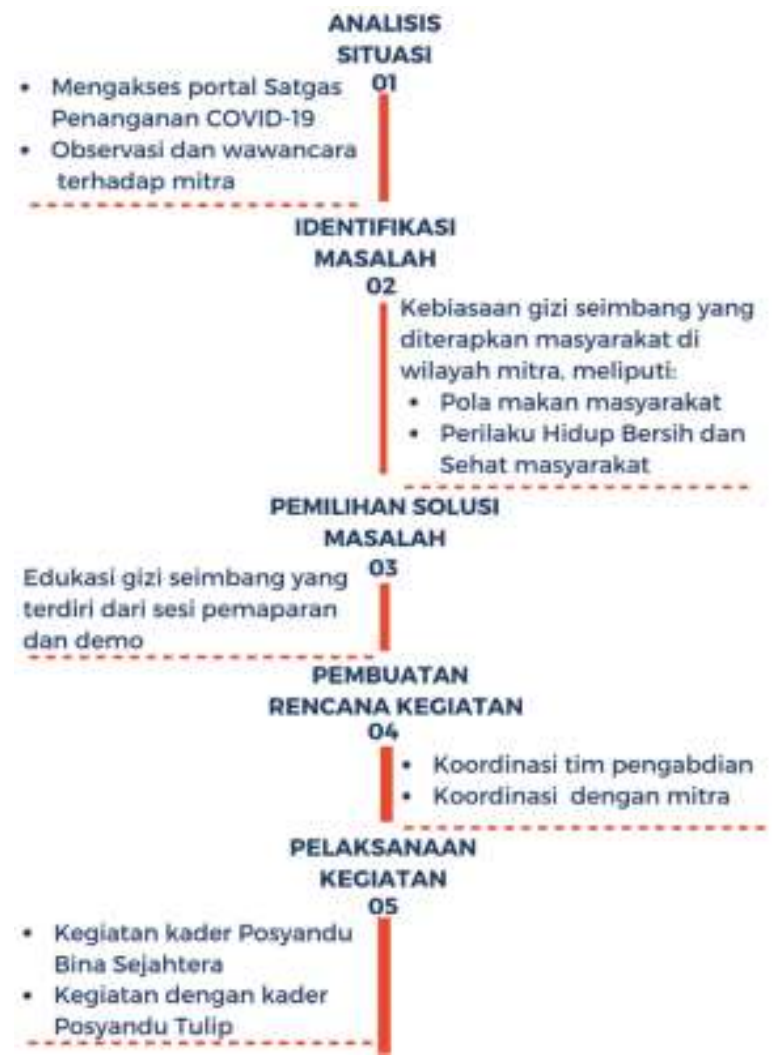

Gambar 1. Alur Pelaksanaan Kegiatan Pengabdian kepada Masyarakat

\section{a. Analisis Situasi}

Pengabdian pada masyarakat diawali dengan tahap analisis situasi. Analisis situasi yang dilakukan yaitu melakukan pencarian data kasus COVID-19 di portal Satgas Penanganan COVID-19 nasional dan portal Satgas Penanganan COVID-19 di Kabupaten Ciamis. Pencarian data ini bertujuan untuk mengamati perkembangan kasus COVID-19. Sebagai upaya memperkuat data hasil pengamatan pada portal tersebut, serangkaian kegiatan observasi dan wawancara dilakukan terhadap masyarakat di wilayah Desa Muktisari Kabupaten Ciamis. Observasi dan wawancara yang dilakukan berkaitan dengan bagaimana konsep gizi seimbang yang diterapkan oleh masyarakat, meliputi pola makan dan kebiasaan PHBS. Pola makan yang dimaksud berupa asupan pangan seimbang dan keamanan pangan yang dikonsumsi sehari-hari, sementara PHBS meliputi kebiasaan mencuci tangan, kebiasaan dalam penggunaan masker, serta aktivitas fisik.

b. Identifikasi Masalah

Berdasarkan analisis situasi, secara umum masalah gizi seimbang yang teridentifikasi meliputi asupan pola makan seimbang yang masih belum dipahami dan 
belum diterapkan dengan benar, kebiasaan PHBS yang masih belum diterapkan secara optimal, asupan pangan seimbang yang belum dikaitkan dengan kebiasaan PHBS, serta pentingnya optimalisasi gizi seimbang sebagai upaya pencegahan COVID-19 yang belum dipahami oleh masyarakat.

c. Penentuan Solusi

Upaya penyelesaian masalah yang teridentifikasi adalah dengan melakukan edukasi secara langsung mengenai pentingnya gizi seimbang di masa pandemi COVID-19. Supaya kegiatan edukasi lebih efektif, sasaran yang dipilih dalam kegiatan ini adalah kader-kader Posyandu. Hasil pemahaman yang diperoleh dari kegiatan edukasi ini harapannya dapat disampaikan secara langsung ke masyarakat oleh kader yang bersangkutan, minimal kepada masyarakat di lingkungan rumahnya.

d. Pembuatan Rencana Kegiatan

Pada tahap ini, serangkaian konsep acara dirancang oleh tim pengabdian dan dikoordinasikan dengan mitra. Secara umum, acara yang dirancang terdiri dari dua bagian, yakni pemaparan materi edukasi gizi seimbang dan demo masak bersama ibu-ibu kader Posyandu. Untuk media edukasi gizi seimbang, selain

\section{HASIL DAN PEMBAHASAN}

Kegiatan pengabdian "Edukasi Gizi Seimbang sebagai Perisai COVID-19" berjalan dengan lancar. Pelaksanaan kegiatan dilaksanakan selama dua hari, yakni Tanggal 3 Oktober 2020 dengan peserta Kader Posyandu Bina Sejahtera dan Tanggal 4 Oktober dengan peserta Kader Posyandu Tulip. Kegiatan berlangsung selama kurang lebih 4 jam dengan menerapkan protokol kesehatan yang cukup ketat. Kegiatan utama yang mengggunakan power point interactive, tim pengabdian juga mempersiapkan booklet materi yang dibagikan sebelum pemaparan materi gizi seimbang. Selain mempersiapkan media edukasi, tim pengabdian juga mempersiapkan intrumen untuk menilai pemahaman peserta sebelum dan sesudah diberikan edukasi gizi seimbang. Intrumen terdiri dari 15 soal pilihan ganda terkait materi yang dipaparkan. Data hasil penilaian akan diolah menjadi nilai n-gain yang menunjukan seberapa besar peningkatan antara hasil pre-test dan hasil post-test. Karena kegiatan yang dirancang sedapat mungkin harus tetap mematuhi protokol kesehatan, berbagai perlengkapan kesehatan dipersiapkan untuk setiap peserta, seperti masker, hand sanitizer, dan sarung tangan.

e. Pelaksanaan Kegiatan

Pelaksanaan kegiatan berlangsung selama dua hari. Pada hari pertama, kegiatan dilaksanakan di Posyandu Bina Sejahtera dengan jumlah peserta 25 orang. Sementara itu, pada hari kedua, kegiatan dilaksanakan di Posyandu Tulip dengan peserta sejumlah 25 orang. Di awal dan di akhir kegiatan, 15 soal intrumen pilihan ganda diberikan sebagai bahan evaluasi kegiatan pengabdian ini.

terdiri dari pemaparan materi dan demo masak terealisasi sesuai dengan rencana kegiatan yang telah dibuat.

Sebelum pemaparan materi dilaksanakan, peserta terlebih dahulu diberikan instrumen penilaian pre-test berupa 15 soal pilihan ganda yang berkaitan dengan gizi seimbang. Selanjutnya kegiatan pemaparan materi disampaikan melalui media Power Point Interactive dan media booklet yang 
dibagikan kepada setiap peserta. Pemilihan media booklet sebagai media pendukung dalam pemaparan mengacu pada efektivitas media booklet untuk meningkatkan pengetahuan dalam penyuluhan (Puspitaningsum, et.al, 2017; Zulaekah, 2012). Booklet yang dicetak berisi materi informatif mengenai gizi seimbang Penjelasan materi di dalam booklet dibuat semenarik mungkin sehingga tidak hanya dapat dibaca oleh ibu-ibu saja, tetapi dapat dibaca juga oleh anak-anaknya di rumah. Penyampaian materi diawali dengan penjelasan singkat mengenai perkembangan singkat kasus COVID-19, gejala orang yang terinfeksi, dan pentingnya menjaga imunitas di masa pandemi. Penyampaian singkat mengenai COVID-19 bertujuan untuk meningkatkan kewaspadaan pada peserta. Adapun materi inti dari kegiatan ini terdiri dari konsep umum gizi seimbang, asupan pangan seimbang, zat gizi yang diperlukan untuk menjaga imunitas tubuh, keamanan pangan yang harus diperhatikan pada saat mengolah makanan, aktivitas fisik yang harus dilakukan untuk menjaga keseimbangan tubuh dengan olahan pangan yang dikonsumsi, kebiasaan mencuci tangan yang baik dan benar, penggunaan masker yang benar, etika bersin di depan umum, serta perilaku physical distancing dan social distancing.

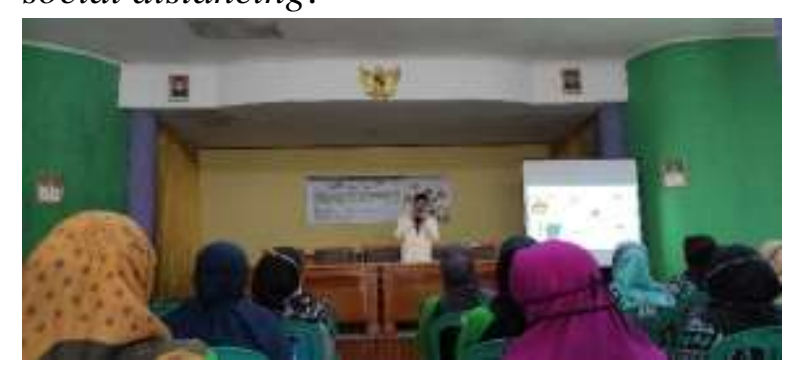

Gambar 2. Pemaparan Materi Gizi Seimbang

Kegiatan pemaparan materi dapat dilihat pada Gambar 2. Pada saat kegiatan berlangsung, seluruh peserta merespon positif terhadap pemaparan yang disampaikan. Bahkan pada saat sesi tanya jawab, peserta tidak segan untuk bertanya kepada narasumber. Salah satu pertanyaan yang diajukan adalah mengenai kendala penggunaan masker yang di beberapa kesempatan terasa berat dikarenakan menimbulkan rasa panas dan sesak. Di akhir sesi pemaparan, peserta diberikan soal instrumen penilaian posttest.

Berdasarkan hasil pre-test post-test, diperoleh nilai $n$-gain sebesar 0,2 . Hal ini menunjukkan bahwa terdapat peningkatan pemahaman mengenai gizi seimbang pada kader Posyandu. Secara grafik, peningkatan skor pre-test dan post-test peserta dari Posyandu Bina Sejahtera dan Posyandu Tulip dapat dilihat pada Gambar 3.

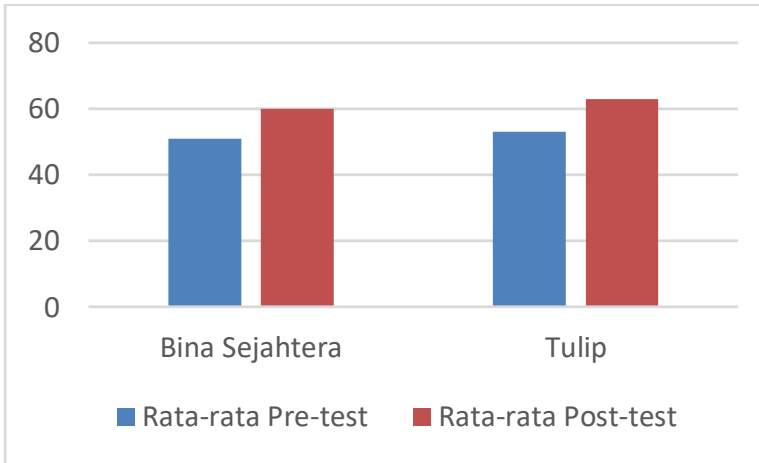

Gambar 3. Grafik peningkatan skor pre-test dan post-test Posyandu Bina Sejahtera dan Posyandu Tulip.

Nilai rata-rata pre-test dan post-test kader Posyandu Bina Sejahtera secara berturut-turut adalah 51 dan dan 60 . Sementara itu, untuk kader Posyandu Tulip nilai pre-test dan post-testnya adalah 53 dan 63. Dari total 15 soal pilihan ganda yang diberikan, bagian yang mayoritas salah adalah soal mengenai jumlah kandungan minimum kandungan gula yang dapat dikonsumsi dalam sehari serta kandungan vitamin 
dan mineral dalam beberapa makanan. Retensi terhadap soal-soal demikian memang sedikit sulit dikarenakan memerlukan daya ingat dan konsentrasi tinggi. Faktor lainnya yang mempengaruhi adalah kondisi peserta yang tingkat konsentrasinya mulai berkurang pada saat post-test.

Secara statistik, peningkatan pemahaman kader Posyandu tidak terlalu besar, tetapi dengan dibekali booklet materi, kader-kader tersebut dapat memahami kembali materi yang telah dipaparkan secara mandiri. Selain itu, kader Posyandu Bina Sejahtera dan Posyandu Tulip termasuk kader yang kesehariannya aktif dalam berbagi informasi, baik melalui online maupun secara langsung. Dengan demikian, informasi mengenai urgensi gizi seimbang sebagai perisai COVID-19 dapat dengan mudah tersebar secara merata kepada masyarakat sekitar, minimal lingkungan rumah terdekat.

Faktor lainnya yang mempengaruhi peningkatan pemahaman yang tidak terlalu besar adalah media yang digunakan pada saat pemaparan materi. Sebetulnya media power point dan booklet yang digunakan sudah baik, tetapi akan lebih maksimal apabila ditambahkan media audiovisual berupa video di dalam

\section{SIMPULAN}

Kegiatan pengabdian edukasi gizi seimbang terdiri dari dua kegiatan utama, yakni pemaparan materi menggunakan media power point interactive dan media booklet serta kegiatan demo masak. Berdasarkan hasil pengolahan data pretest dan post-test, nilai n-gain yang diperoleh adalah sebesar 0,2. Perolehan nilai ini menunjukkan bahwa terdapat proses pemaparan materi. Menurut Idris et al., (2018), seorang pembelajar akan lebih mempertahankan apa yang ia pelajari apabila dalam proses pemerolehan pengetahuan tersebut melibatkan berbagai alat indera. Hal ini menunjukkan bahwa media audiovisual mampu meningkatkan retensi peserta terhadap materi.

Rangkaian kegiatan ditutup dengan kegiatan demo masak sederhana. Demo masak yang dilakukan bertujuan untuk mengaplikasikan pemahaman yang telah peserta dapatkan dari sesi pemaparan materi. Penjelasan mengenai kandungan zat gizi yang terkandung dalam buahbuahan, susu, yoghurt, dan keju kemudian diolah menjadi kudapan praktis dan bergizi yaitu salad buah. Teknis demo masak dibagi menjadi empat kelompok. Masingmasing kelompok mempraktikkan pembuatan salad buah yang dicontohkan oleh tim pengabdian. Hasil demo masak yang telah dilakukan setiap kelompok kader dapat dilihat pada Gambar 4.

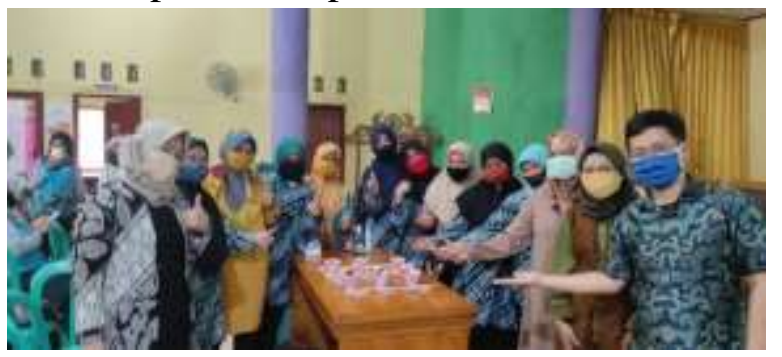

Gambar 4. Demo masak gizi seimbang

peningkatan pemahaman kader Posyandu Bina Sejahtera dan Posyandu Tulip sebelum dan sesudah diberi edukasi gizi seimbang. Beberapa hal masih perlu dievaluasi dalam kegiatan pengabdian ini, salah satunya adalah pemilihan media yang digunakan dalam penyampaian edukasi. Hasil evaluasi ini diharapkan dapat menjadi bahan masukan untuk tim 
pengabdian dalam melaksanakan kegiatan serupa di masa mendatang.

\section{DAFTAR PUSTAKA}

Calder, P. C. (2020). Nutrition, immunity and COVID-19. https://doi.org/10.1136/bmjnph2020-000085

Ibrahim K.S; El-Sayed E.M. (2016). Potential role of nutrients on immunity $1 *$. 23(2), 464-474.

Idris, A. T., Shamsuddin, I. M., Arome, A. T., \& Aminu, I. (2018). Use of Audio-Visual Materials in Teaching and Learning of Classification of Living Things Among Secondary School Students in Sabon Gari LGA of Kaduna State. 6(2), 33-37. https://doi.org/10.11648/j.plant.2018 0602.12

Pusat Informasi \& Koordinasi COVID-19. (n.d.). Retrieved June 13, 2020, from https://pikobar.jabarprov.go.id/

Puspitaningsum, W., E. a. (2017). Pengaruh Media Booklet Terhadap Pengetahuan Dan Sikap Remaja Putri Terkait Kebersihan Dalam Menstruasi Di Pondok Pesantren AlIshlah Demak Triwulan Ii Tahun
2017. 5(4), 274-281.

Satgas Penanganan COVID-19. (n.d.). https://covid19.go.id/

Susilo, A., Rumende, C. M., Pitoyo, C. W., Santoso, W. D., Yulianti, M., Sinto, R., Singh, G., Nainggolan, L., Nelwan, E. J., Khie, L., Widhani, A., Wijaya, E., Wicaksana, B., Maksum, M., Annisa, F., Jasirwan, O. M., Yunihastuti, E., Penanganan, T., New, I., ... Cipto, R. (2020). Coronavirus Disease 2019: Tinjauan Literatur Terkini Coronavirus Disease 2019: Review of Current Literatures. 7(1), 45-67.

Tse, A. D. P., Suprojo, A., \& Adiwidjaja, I. (2017). Jurnal Kesehatan Masyarakat. 6(1), 60-62.

Zulaekah, S. (2012). Pendidikan Gizi dengan Media Booklet terhadap Pengetahuan Gizi. Jurnal Kesehatan Masyarakat, 7(2), 127-133. https://journal.unnes.ac.id/nju/index. php/kemas/article/view/2808 